\title{
Exploring the secrets of the three-dimensional architecture of phototrophic biofilms in caves
}

\author{
Mònica Roldán ${ }^{1} \&$ Mariona Hernández-Mariné2
}

\begin{abstract}
:
Roldán M. and Hernández-Mariné M. 2009. Exploring the secrets of the three-dimensional architecture of phototrophic biofilms in caves. International Journal of Speleology, 38 (1), 41-53. Bologna (Italy). ISSN 0392-6672.

Caves with dim natural light, and lighted hypogean environments, have been found to host phototrophic microorganisms from various taxonomic groups. These microorganisms group themselves into assemblies known as communities or biofilms, which are associated with rock surfaces. In this work, the phototrophic biofilms that colonise speleothems, walls and floors in three tourist caves (Spain) were studied. Confocal laser scanning microscopy (CLSM) and scanning electron microscopy (SEM) were used to study these organisms and acquire three-dimensional data on their biofilm structure. CLSM was used in a multi-channel mode whereby the different channels map individual biofilm components. Cyanobacteria, green microalgae, diatoms, mosses and lichens were found to be grouped as biofilms that differed according to the sampling sites. The biofilms were classified into six types regarding their environmental conditions. These types were defined by their constituent organisms, the thickness of their photosynthetic layers and their structure. Light-related stress is associated with lower biofilm thickness and species diversity, as is low humidity, and, in the case of artificially illuminated areas, the duration of light exposure.
\end{abstract}

Keywords: biofilms, caves, cyanobacteria, chlorophyta, Spain.

Received 8 July 2008; Revised 25 September 2008; Accepted 3 October 2008

\section{INTRODUCTION}

Biofilms are collectives of one or more species of microorganisms. They provide protection for growth, enabling microorganisms to survive hostile environments (Prakash et al., 2003) and are significant in sediment stabilization and construction (Golubic \& Schneider, 2003). Biofilms comprise sessile microorganisms in different stages of growth; hence, they respond quickly to variable conditions (Costerton et al., 1987).

When microorganisms adhere to a surface, their immobilised cells grow, replicate and secrete extracellular polymeric substances (EPS) that engulf them in a gelatinous matrix (Brading et al., 1995). The development of complex, adhered or aggregated communities plays a key role in the survival and reproductive success of the microorganisms involved. Biofilms can provide refuge for species that face

1 Servei de Microscòpia. Universitat Autònoma de Barcelona. Edifici C, Facultat de Ciències. E-08193, Bellaterra, Spain. e-mail: monica.roldan@uab.es

2 Unitat de Botánica. Facultat de Farmacia. Universitat de Barcelona. Av. Joan XXIII s/n E-08028, Barcelona, Spain. e-mail: marionahernandez@ub.edu competition, predation or unfavourable environmental conditions (Korber et al., 1994).

Biofilms develop according to their environmental conditions and the physicochemical properties of their substrate (Walker \& Pace, 2007). Research has shown that the coexistence of species in a biofilm depends on its capacity-and that of its competitors-to bind to its substrate (Stewart, 1997). Mixed biofilms are thicker and more stable to environmental stress than monospecific biofilms. This may be due to the production of a broader array of EPS by a greater variety of microorganisms (Kumar \& Anand, 1998).

Natural biofilms can be highly organised, may encompass one or several species, and can form a single layer, a three-dimensional structure or even aggregates (Bryers, 1987, Bagge et al., 2001). The three-dimensional structure of a biofilm is related to its functions and to the survival of its constituent organisms and depends on environmental factors (Hall-Stoodley et al., 2004, Wimpenny et al., 2000). Biofilm structure can be dictated by numerous conditions, such as spatial and temporal differences in light and humidity, as well as surface and interface properties, nutrient availability and the composition of the microbial community (Davey \& O'Toole, 2000). Biofilms differ in their architecture. Due to their 
depth, some biofilms are highly stratified (Zhang \& Bishop, 1994).

To understand how certain microorganisms colonise their environments, these organisms not only need to be identified, but also understood at the level of community organisation (Albertano \& Urzi, 1999; Hernández Mariné et al., 2001b, 2003; Roldán et al., 2004b). Likewise, the nature of the substrate can affect the binding pattern. For example, on hydrophilic surfaces, microorganisms tend to uniformly adhere as a monolayer, whereas on hydrophobic surfaces, they tend to adhere en masse (McEldowney \& Fletcher, 1987), which is facilitated by their EPS.

Caves with dim natural light have been found to host phototrophic microorganisms from various taxonomic groups, including cyanobacteria, chlorophytes, bacillariophytes and lichens. Confined caves with a large volume of rock are usually characterised by homogeneous air temperatures and stable conditions. Humidity is usually high (Hernandez-Mariné et al., 1999, Roldán et al. 2004b). Limited photosynthetically active radiation (PAR) provides pressure for selection and is the principal determinant of whether a biofilm will tend towards autotrophy (i.e. algae and cyanobacteria) or heterotrophy (i.e. fungi and bacteria) as well as of the depth at which a biofilm will penetrate the cave interior. Communities of microorganisms organise themselves according to these gradients of light, whether natural or artificial. Nonetheless, neither the distribution of organisms within a rock, nor the balance between autotrophy and heterotrophy within a biofilm, is controlled exclusively by light. For example, the ratio of algae to bacteria can be influenced by the availability of nutrients or organic material (Ohki \& Gantt, 1983).

Since the famous study of green sickness (Lefèvre et al., 1964), which affected the Paleolithic paintings in the Cave of Lascaux, France, the presence of photosynthetic microorganisms in the walls and paintings of caves and monuments has been reported. Artificially illuminated hypogean environments include tombs and Roman catacombs (Albertano et al., 2003). Cyanobacteria and bacillariophytes also have been reported in monuments such as the Parthenon in Athens (Anagnostidis et al., 1983), in construction materials in the cathedrals of Seville, Salamanca and Toledo (Ortega Calvo et al., 1991, 1993), and in Granada (Sánchez Castillo, 1981, 1983). Other studies have focused on cyanobacteria that affect stone monuments in tandem with lichens (Danin \& Caneva, 1990). Additionally, microalgae have been observed growing on mural paintings (Grilli Caiola et al., 1987; Albertano et al., 1991) and on church frescoes (Pietrini \& Ricci, 1993) in Italy. Many of the species found in these locations exhibit a tropical or Atlantic distribution and can be found in related environments such as land that lacks vegetation cover. The great diversity and broad distribution of photosynthetic organisms in these environments is reflected in the abundant literature on them (Hoffmann, 1989, 2002). Hypogean environments are typically equipped with artificial illumination, primarily for tourism. Depending on the intensity, quality and duration of the illumination, these areas can generate conditions which favour photoautotrophic growth, thereby enabling photosynthetic organisms, known as Lampenflora (Abdelahad, 1989; Smith \& Olson, 2007) to extend into previously uncolonised areas (Hoffmann, 1989, 2002).

Hypogean environments have been studied on nearly every continent, namely, in Brazil (Sant'Anna et al., 1991); Israel (Friedmann, 1955, 1964; Vinogradova et al., 1998); Florida and the Cook Islands (Friedmann, 1979); the Bahamas (Davis \& Rands, 1981); Hungary (Claus, 1964; Hajdu, 1966; Kol, 1966; Komáromy, 1977; Komáromy et al. 1985); France (Bourrelly \& Dupuy, 1973; Leclerc et al., 1983); Germany (Dobat, 1977); Belgium (Garbacki et al., 1999); Italy (Abdelahad \& Bazzichelli, 1988; Borzi, 1917; Skuja, 1970); Romania (Serbanescu \& Decu, 1962); Croatia, Slovenia (Golubic, 1967); and Scotland (Carter, 1971). In Spain, caves and related environments have primarily been studied in Barcelona, Seville, Oviedo (Ariño et al., 1997; Hernández-Mariné et al., 2001b; Roldán et al., 2004b) and Murcia (Aboal et al. 1994; Asencio \& Aboal, 1996, 2000).

The aforementioned locations host myriad cyanobacterial species, including Myxosarcina, in caves in Italy (Abdelahad, 1989); Geitleria calcarea, reported in caves (Friedmann, 1955) throughout France (Bourrelly \& Dupuy, 1973; Leclerc et al., 1983), Italy (Abdelahad \& Bazzichelli, 1988) and Spain (Gracia Alonso, 1974; Hernández-Mariné \& Canals, 1994a); and Scytonema julianum, reported throughout Europe (Couté \& Bury, 1988; Dobat, 1977; Garbacki et al., 1999; Hoffmann, 1989), including Spain (Ariño et al., 1997; Aboal et al. 1994; Hernández-Mariné \& Canals, 1994a). Further study of these environments has led to observation of rare or even undocumented species such as Herpyzonema pulverulentum (HernándezMariné \& Canals, 1994b), Loriella sp. (HernándezMariné et al., 1999) and Symphyonema cavernicolum (Asencio et al., 1996), filamentous cyanobacteria with calcified sheaths that have been reported in Spanish caves.

Another frequently observed group in caves is the Bacillariophyta. Whilst numerous species have been described on different continents, the most widely cited species are typically cosmopolitan and not very specific to the environments. Diverse species have been found in the United States (Saint-Clair \& Rushforth, 1976), Scotland (Carter, 1971), Rome (Albertano et al., 1994) and Spain (Roldán et al., 2004b), including species from the genera Diadesmis, Achnantes, Nitzschia, Cymbella and Orthoseira (as Melosira).

Among chlorophytes in caves, the unicellular forms - the taxonomy of which is highly problematictend to dominate. These include Bracteococcus minor (Chlorophyta) (Lefèvre, 1974), the causative agent of green sickness in the Cave of Lascaux, France (Lefèvre et al., 1964). Chlorophyta species have been reported in other environments, including aeroterrestrial green microalgae (Crispim et al., 2003; Kumar et al., 2007; Tomaselli et al., 2000) or growing free living on tree 
bark, soil and rock or as lichen photobionts (Ettl \& Gärtner, 1995; Kumar \& Kumar, 1999).

These organisms are named according to their position relative to the substrate (Golubic et al., 1981): those which colonise rock surfaces are known as epiliths, whereas those which colonise rock interiors are known as endoliths. The latter group includes chasmoendoliths, which colonise cracks in rocks.

The aims of the present study were to evaluate the biodiversity of photosynthetic microorganisms dwelling in the show artificially illuminated caves of Zuheros, Nerja and Collbatò (Spain) and to characterise the 3D structure of their respective biofilms, in order to provide information for improving control strategies.

\section{MATERIALS AND METHODS}

\section{Source of the materials}

We collected biofilm samples from three Spanish caves: Zuheros (Hernanz et al., 2006) and Nerja (Sanchidrián, 1986), which feature Palaeolithic rock paintings, and the show cave of Collbato. In all of these caves biofilm development was favoured by anthropogenic factors such as high $\mathrm{CO}_{2}$ concentration and artificial illumination. Fragments of biofilms were collected together with small pieces of their support from rock substrata, speleothems, cave walls and floors.

The Cave of Bats is located at a height of $972 \mathrm{~m}$ a.s.1, close to the village of Zuheros (Córdoba, southern Spain). The continental Mediterranean climate of the area is characterised by a mean annual temperature of $14.9{ }^{\circ} \mathrm{C}$, ranging from $-10^{\circ} \mathrm{C}$ in winter to over 40 ${ }^{\circ} \mathrm{C}$ in summer, as well as by a high rate of rainfall, with maxima in November and February. The Cave of Bats has an opening at each end. These provide a high rate of natural ventilation, and relatively low air humidity compared to the other caves studied, and influences the internal temperature. Substrata consist of limestone rock that was partially covered by calcitic crusts and speleothems. Some areas were covered by bat droppings (Albertano et al., 2003). Six points in Zuheros cave were selected for study: $Z 1$ to $Z 3$ (speleothems or calcite with crust), which are located near the visitor entrance and receive both natural and artificial light; Z4 (white calcite), which have biofilms developed on dripping tracks and are illuminated artificially; Z6 is submitted only to artificial lighting for a short time during visits and $Z 7$ and $Z 8$ (calcite or speleothem), which are located in the exit hall and receive only natural light. PAR (photosynthetically active radiation) varies from 3.8 to $18 \mu \mathrm{mol} \mathrm{m}^{-2} \mathrm{~s}^{-1}$ at the entrance and from 0.05 to $5.0 \mu \mathrm{mol} \mathrm{m}^{-2} \mathrm{~s}^{-1}$ inside the cave (Albertano et al., 2003).

The Nerja Cave (Màlaga) is less than $1 \mathrm{~km}$ from the coast line. Its entrance is at $158 \mathrm{~m}$ a.s.1. The cave lies within dolomitic marble. Air temperature in the cave is ca. $19^{\circ} \mathrm{C}$ year round. Sampling site N5 is artificially illuminated during visits; sampling site N6 receives scarce natural light. The ambient humidity is between $84 \%$ and $99.9 \%$ at the sampling zones. Water from adjacent mountains enters the Cave, with maximum dripping in August.

The Salpetre Cave of Collbato (near Barcelona) is located at $500 \mathrm{~m}$ a.s.1. The representative sampling zone, Virgin Cave, is located at the bottom of the cave. The substrate comprises a flat, vertical calcite surface with clay impurities from decalcification. The only light that the Cave receives is artificial light during visits. It shows relative micro-environmental stability throughout the annual cycle: the mean value of the air temperature is $14.7{ }^{\circ} \mathrm{C}$, with an annual variation of $4.1^{\circ} \mathrm{C}$; the mean value of the stone temperature is $15.5^{\circ} \mathrm{C}$, with an annual variation of $1.2^{\circ} \mathrm{C}$; and the ambient humidity is $99.9 \%$ at the sampling zone. Light is provided by incandescent lamps (Sylvania 80W, Holland).

\section{Preparation and staining of material}

We used an array of microscopy techniques to visualise the samples: scanning electron microscopy (SEM) and confocal laser scanning microscopy (CLSM) combined with lectin labelling.

\section{SEM}

Samples were processed with an acrolein-osmium fixation technique (Hernández-Mariné et al., 2001a) and viewed using a Hitachi S-2300 microscope. The biofilm was pre-fixed in acrolein vapour in a closed chamber with silica gel for 10 days. Post-fixation was carried out in osmium tetroxide vapour in the same chamber for an additional 5 days. Samples were double coated with carbon, using a rotary holder and sputtered gold. We used this technique for samples prone to collapse, as it affords adequate preservation of three-dimensional structures (Hernández-Mariné et al., 2001a). Small stones or filters may also be mounted on the stubs with double-sided adhesive tape and coated.

\section{CLSM}

The biofilms were examined using a confocal spectral Leica TCS SP2 (Leica Microsystems, Mannheim, Germany). All experiments employed a x10 (0.4 NA), a $x 40$ (1.25 to $0.75 \mathrm{NA})$, and a x63 (1.32 NA) Plan Apochromat oil immersion objective. The $488 \mathrm{~nm}$ line of an Ar laser was used for imaging EPS (green channel, emission at 490 to $530 \mathrm{~nm}$ ). EPS were labelled with the broad-spectrum, carbohydrate-recognizing lectin concanavalin-A (Molecular Probes, Inc., Eugene, OR, USA)—which binds to mannose and glucose residues-at a final concentration $0.8 \mathrm{mM}$. Nucleic acids were stained with the DNA selective dye Hoechst 33258 (Sigma Aldrich, St. Louis, MO, USA) and viewed in the blue channel (excitation at 351 and 364 $\mathrm{nm}$ and emission at 400-480 nm). Autofluorescence was used for imaging photosynthetic pigments at 543 and $633 \mathrm{~nm}$ excitation wavelengths $(\mathrm{He}-\mathrm{Ne})$ and in the 590-to $800 \mathrm{~nm}$ emission range (red channel). Phycoerythrin and chlorophyll $a$ fluorescence were detected between $555-595 \mathrm{~nm}$ and $690-750 \mathrm{~nm}$ respectively by excitation with a $488 \mathrm{~nm}$ argon laser. The reflection image (grey channel, excitation at 488 $\mathrm{nm}$ and emission at 480 to $490 \mathrm{~nm}$ ) was used to 
visualise the external surfaces and mineral particles. Fluorescence emission was then sequentially collected in the green and red regions of the spectrum. Line averaging $(\mathrm{x} 4)$ was used to capture images with low noise. Data consists of a set of two dimensional (2D), cross-sectional image in the $\mathrm{x}-\mathrm{y}$ plane that is captured along the $z$-axis. Natural fluorescence of chlorophyll pigments and phycobiliproteins was used to trace the internal distribution of microalgae and cyanobacteria. The CLSM data were visualised in different projections (Roldán et al. 2004a) using Imaris software (Bitplane AG Zürich, Switzerland). The side views of the 3D reconstructed images were used to determine biofilm architecture.

\section{RESULTS}

The photosynthetic communities that inhabit the cave rocks thrive mainly on the surface. Walls, speleothems, stalagmites and stalactites provide a variety of ecological niches that primarily undergo nonendolithic colonisation. The upper surfaces appeared blue, greenish or grey as a result of photosynthetic growth. The patinas were continuous, arranged mosaically or spotty. Macroscopic views of biofilms from the caves are shown in Fig. 1 a-e.

The microscopic studies revealed the complexity of these communities and their constituent organisms. SEM enabled visualisation of the surfaces (Fig. 2 a-f), whereas CLSM microscopy allowed taxa identification and cell localisation in the intact biofilms. Fluorescence and Con-A were used in tandem to assess cell viability: metabolically active cells are indicated by pigments, which fluoresce red in the cell cytoplasm. Binding of Con-A to polysaccharides outlines the sheaths and cell walls of nearly all microorganisms, including bacteria and actinobacteria. The images revealed traces of inorganic materials such as substrata and calcified sheaths.

\section{Cave of Bats, Zuheros.}

Sampling point $Z 1$ was covered by a dark green mucilaginous layer (Fig. 1 a). The microflora present comprised the cyanobacteria Aphanocapsa parietina, Cyanosarcina cf. parthenonensis, Gloeocapsa spp, Gloeocapsopsis magma, Leptolyngbya spp., Nostoc sp. and Tolypothrix sp., the clorophytes Chlorella sp., Desmococcus sp., Klebsormidium flaccidum, Trebouxia sp., diatoms and mosses in different states. The cyanobacteria exhibited colourless sheaths. The number of taxa decreased from $Z 1$, at the mouth of the cave and lit by natural light, to Z3, further inside the cave. Indeed, by point $Z 3$, the only species remaining were Cyanosarcina cf. parthenonensis, Chlorella sp., Klebsormidium flaccidum and the diatoms Diadesmis sp. and Nitzschia sp. Bacteria and actinobacteria (Fig.2a) were widespread and entangled with the photosynthetic organisms. The biofilms that encompassed several taxa generally exhibited stratification, with a continuous upper layer of chlorophytes and a discontinuous bottom layer of cyanobacteria (Fig. 3; Type 1 biofilm). The thickness of their photosynthetic layers was $25.5 \pm 4.5 \mu \mathrm{m}$. Any diatoms present were located on the surface. In some cases this layer appeared strongly labelled with con-A. This can be attributed to the EPS, which, despite holding the colonies together, also appeared to delineate the different organisms, especially cyanobacteria or green algae in thick coverings.

The biofilms from $\mathrm{Z} 2$ had the cyanobacteria Gloeothece sp. and Cyanosarcinacf. parthenonensis at

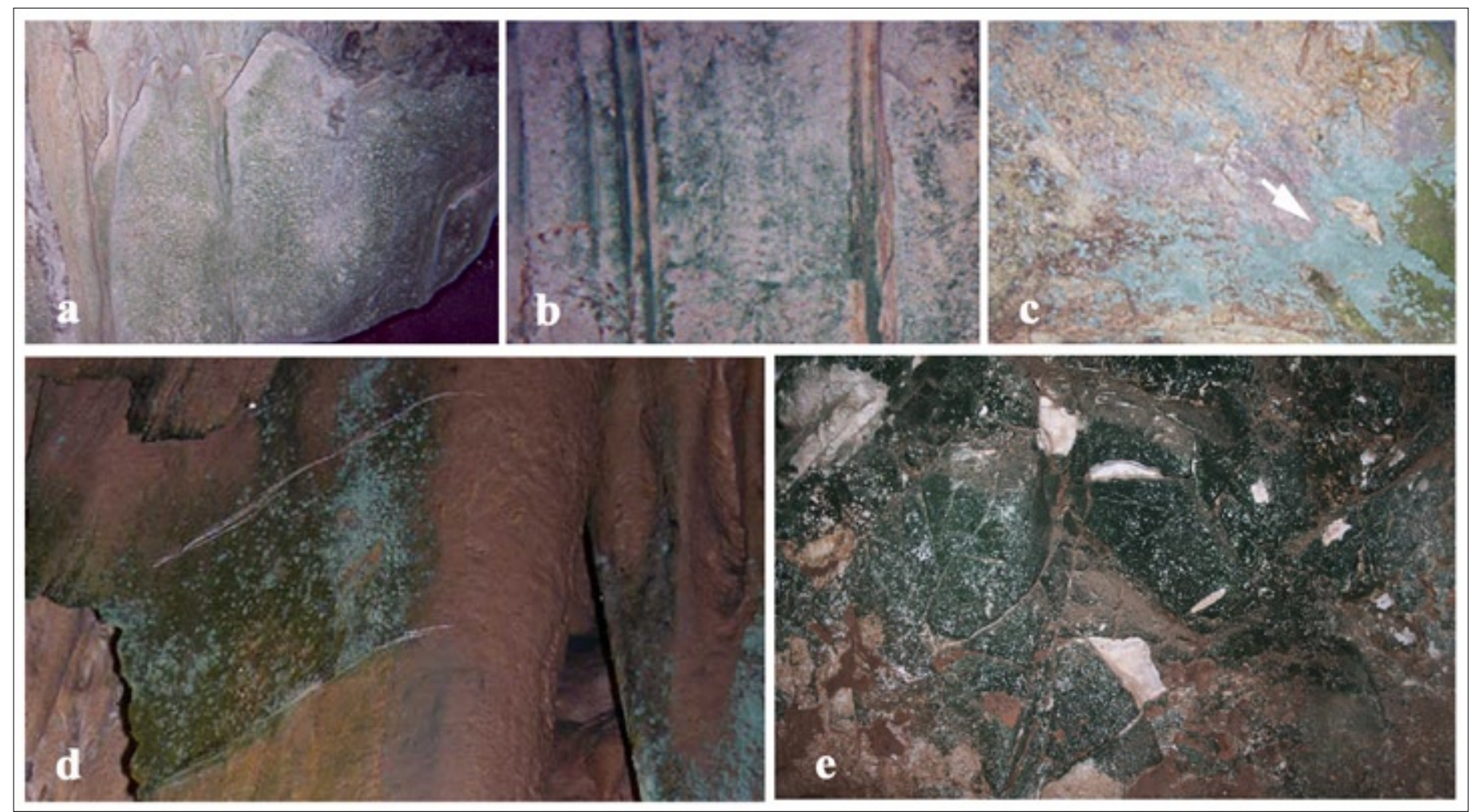

Fig. 1. Macroscopic images from the sampling zones: a. Zuheros (sample Z1); b. Zuheros (sample Z4); c. Zuheros (sample Z7) Leprose lichen (white arrow); d. Collbató (Virgin Cave); e. Nerja (sample N5). 

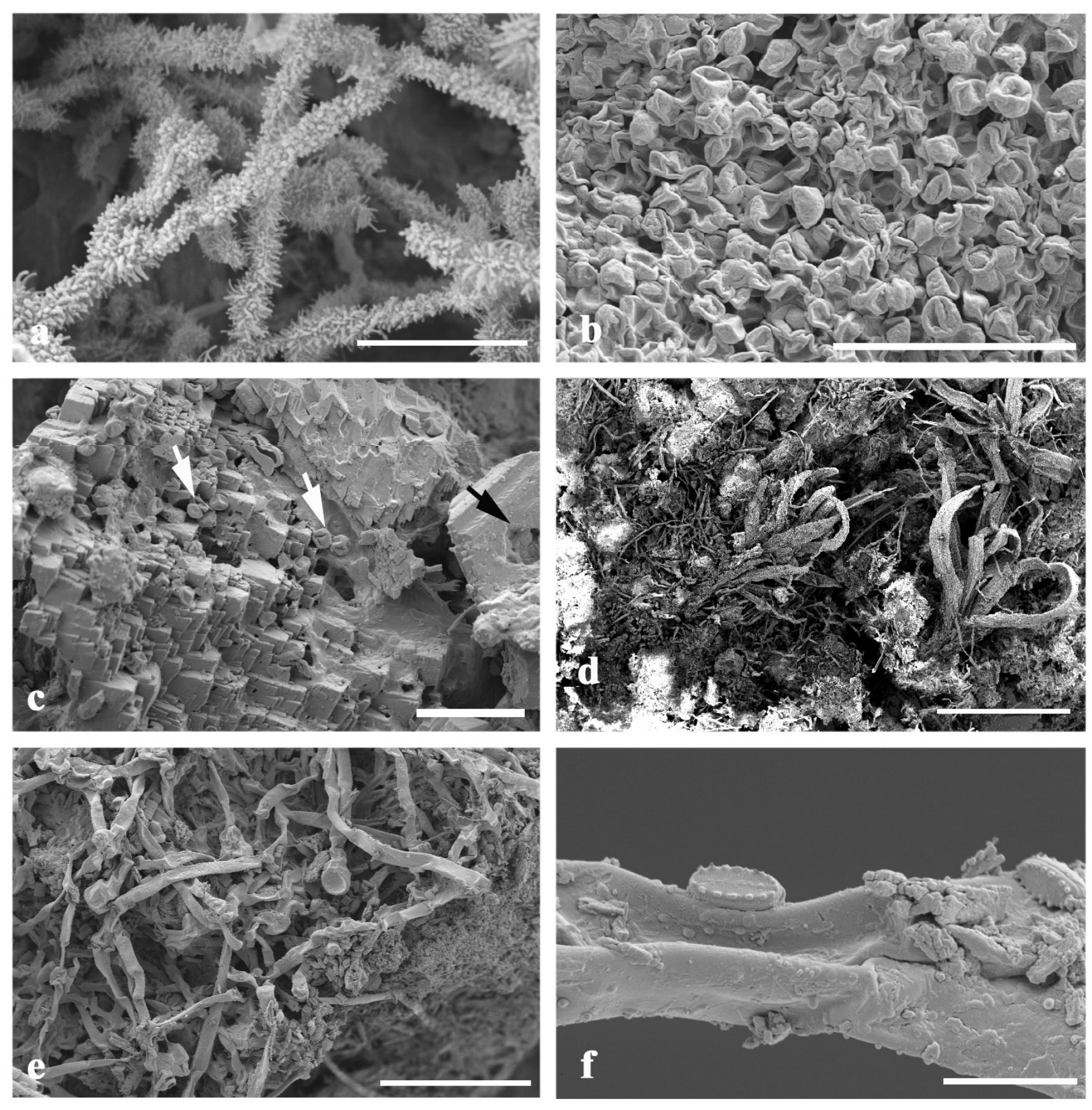

Fig. 2. Scanning electron photomicrographs. a. Z1. Image of a filamentous actinobacterium with crystal formation (scale: $5 \mu \mathrm{m}$ ). b. Z4. Rod-shaped Muriella sp. (Chlorophyta) forming a continuous layer on the surface of a dolomitic rock. Cells are collapsed due to dessication induced by processing of the samples for SEM (scale: $20 \mu \mathrm{m}$ ). c. Z4. Biofilm formed by a single-celled chlorophyta irregularly distributed on a dolomite surface. The white arrows indicate cells on the surface and black arrow shows cells inhabiting a fissure (scale: $20 \mu \mathrm{m}$ ). d. Z6. Biofilm formed of mosses or protonemata epiphyted by Bacillariophyta (Diadesmis sp.) on a speleothem (scale: $1 \mathrm{~mm}$ ). e. Z7. Leprarioid lichen Botryolepraria lesdainii (scale: $100 \mu \mathrm{m}$ ). f. Z7. High magnification showing Diadesmis gallica (diatom) on the lichen Botryolepraria lesdainii (scale: $10 \mu \mathrm{m}$ ).

the bottom, on the surface or in holes, and contained Chlorella sp., and occasionally scarce diatoms, at the top. In samples from Z2, the thickness of the photosynthetic layers was $13.6 \pm 2.2 \mu \mathrm{m}$ (Type 2 biofilm), whereas in samples from $Z 3$, the predominant biofilm was $12.7 \pm 3.6 \mu \mathrm{m}$ (Type 3 biofilm), which did not present stratification.

Sampling point $Z 4$ (Fig. $1 \mathrm{~b}$ ) which receives scarce natural and artifical light, showed thin and compact patches of phototrophic growth, following temporary water tracks; their colour varied from bright blue- green to olive green. The photosynthetic layers were either thin, continuous and compact (Fig. 2 b) or irregularly covering the surface (Fig. 2 c). The most frequently identified organisms were Chlorella sp., Chlorosarcinopsis sp., Muriella sp. and Myrmecia bisecta. Their microflora also included Cyanosarcinacf. parthenonensis, Leptolyngbya cf. lurida, Leptolyngbya spp., Phormidium cf. tenue, Phormidium spp., Chlorella sp., Chlorosarcinopsis sp., Klebsormidium flaccidum, Muriella cf. terrestris, Diadesmis spp., and Orthoseira roseana. Biofilms that only contained one 


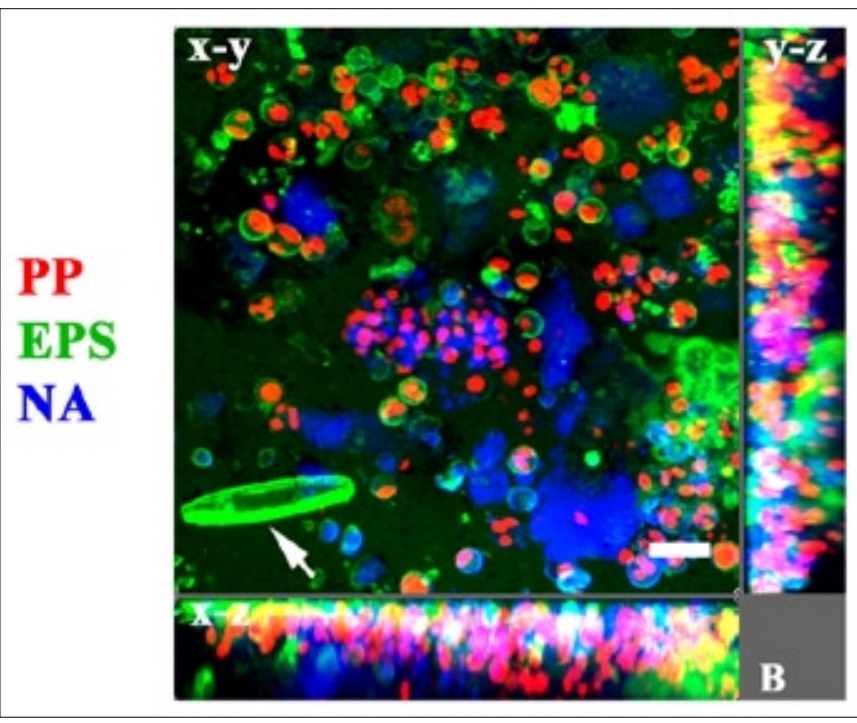

Fig. 3. Confocal photomicrograph. Structure and composition of a stratified Type 1 biofilm, in Zuheros (Z1). Central frame shows the maximum intensity projection of the mixed biofilm. Stratification of the various groups of phototrophic organisms with an upper layer of Chlorophyta (Chlorella sp.), a discontinuous bottom layer of cyanobacteria (Gloeothece sp. and Cyanosarcina cf. parthenonensis), and occasionally, scarce diatoms at the top (white arrow) can be seen in the lateral frames. Three-dimensional extended projections in $x-y$, $x-z$ and $y-z$ views of 42 sections ( $($ tep $=0.4 \mu \mathrm{m}$ ) in the $z$-direction of the biofilm. $16.40 \mu \mathrm{m}$ total thickness.

Colour key: red = autofluorescence of pigments (PP); green = EPS labelled Con-A (EPS), blue = nucleic acids $(N A) . B=$ bottom of the sample (scale: $10 \mu \mathrm{m}$ ).

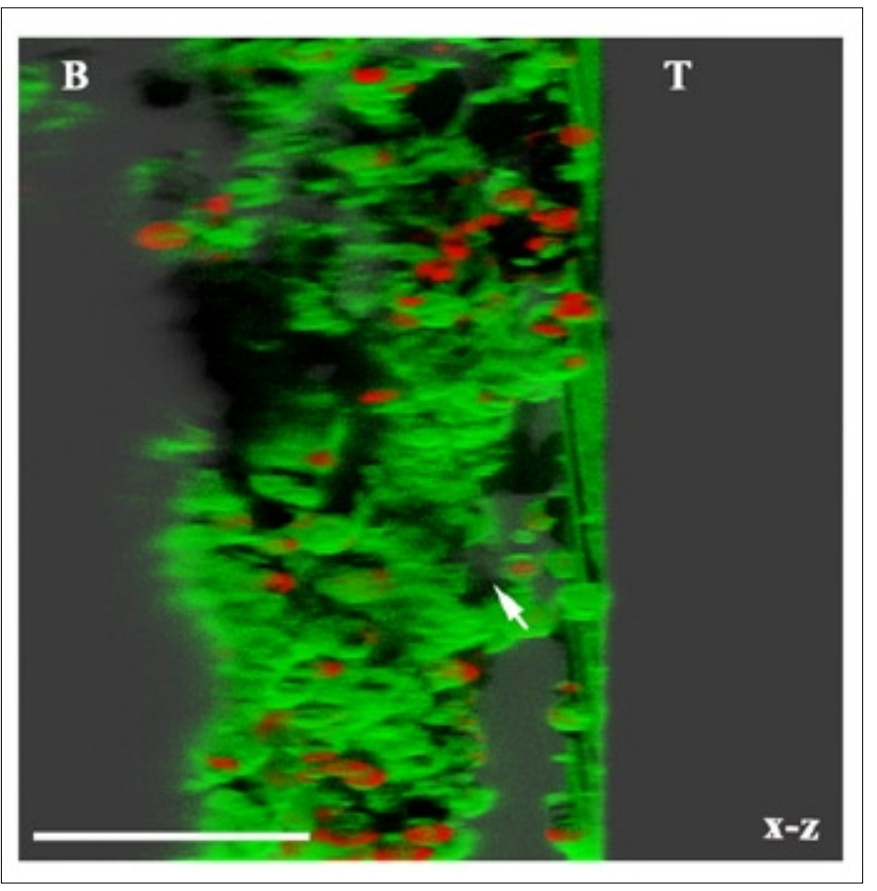

Fig. 4. Confocal photomicrograph. Saggital projection of an unstructured Type 3 biofilm in Zuheros (Z4). a. The distribution of the microorganisms along the $x-y$ axis was irregular; along the $x-z$ axis the biofilm moulded the substrata. Some Chlorella sp. were hidden in small crevices. The EPS was distributed heterogeneously. Bubblelike structures or pores were observed (arrow). Colour key: red = autofluorescence of pigments; green = EPS labelled Con-A. T = top of the sample; $B=$ bottom of the sample (scale: $100 \mu \mathrm{m}$ ). or a few species were flat. Their photosynthetic layer had a thickness of $15.7 \mu \mathrm{m} \pm 6.9 \mu \mathrm{m}$ (Fig. 4). The organisms were irregularly distributed, some patches contained Cyanosarcina cf. parthenonensis coexisting with Chlorella or other chlorophytes (Fig. 5 a-c; Type 2 biofilm). All of these were either on the substrate or hidden inside of it. Their fluorescent layers had a thickness of $16.3 \pm 3.8 \mu \mathrm{m}$.

At Z6, which only receives irregular artificial light, there was a thin, green layer with a thickness of $14.9 \pm$ $3.2 \mu \mathrm{m}$, formed of Chlorella sp., either alone or mixed with moss protonema or developed mosses (Fig. $2 \mathrm{~d}$; Type 4 biofilm). In the biofilms dominated by welldeveloped mosses, the fronds appeared epiphyted by Diadesmis gallica. They were only locally abundant on walls of calcite microgours (humid areas with dripping water).

The sampling points near the exit, Z7 and Z8 (Fig. 2 e, f), were covered by a discontinuous layer with irregular colouration. At the outermost points, the stains were greyish and primarily formed of the lichen Botryolepraria lesdainii, with the basal layer composed of their phycobiont Coccobotrys verrucariae, in free-living state (Fig. 6, Type 5 biofilm), as well as other green algae such as Trebouxia sp., which also formed lichens (Fig. 6 b). Some of the lichens appeared to be covered by diatoms (Fig. $2 \mathrm{f}$ ) or other microorganisms. At the rock entrances and in the most-protected zones, the patches were greenish-grey, or green and gelatinous when hydrated, owing to the presence of the green algae Trebouxia sp., Chlorella-like, Stichococcus bacillaris and Leptosira sp. Trentepohlia sp. was present in scarce amounts and did not contribute to the formation of lichens. The different biofilms on the rock varied widely in their thickness. The biofilms composed of diverse chlorophytes had a thickness of $13.7 \pm 1.1 \mu \mathrm{m}$ (Type 3 biofilm), almost the same as that of the biofilms comprised of only a single species $(6.5 \pm 3.2 \mu \mathrm{m})$. Naturally or artificially illuminated crevices under high relative humidity were dominated by mosses, on which grew the centric diatom Orthoseira roeseana (Fig. $6 \mathrm{c}$ ) and the pennate Diadesmis gallica. However, both diatoms were often found dead or in a senescent state, as indicated by their total or nearly total lack of fluorescence.

\section{Biofilms in Nerja.}

The patina that colonised the sampling point N5 (Fig. 1 e) grew as a thin, discontinuous layer on surface areas, natural cracks and fissures (Fig. 7 a, b). The dominant photosynthetic organism was Muriella sp., located on the surface or in open crevices or pits (Fig. $7 \mathrm{a}, \mathrm{b})$. The photosynthetic layer that covered the rock was very thin, sometimes comprising only a single layer of cells (Type 3 biofilm), although it appeared thicker since this layer covered sharp rock and cracks. Nostoc sp. and coccal cyanobacteria were present at very close points (N6) exposed to natural light (Fig. 7 c).

\section{Biofilm in Collbató.}

The stalactite surface (Fig. 1 d) was covered with a greyish-white, porous mass primarily composed of the filamentous cyanobacterium Scytonema julianum, 


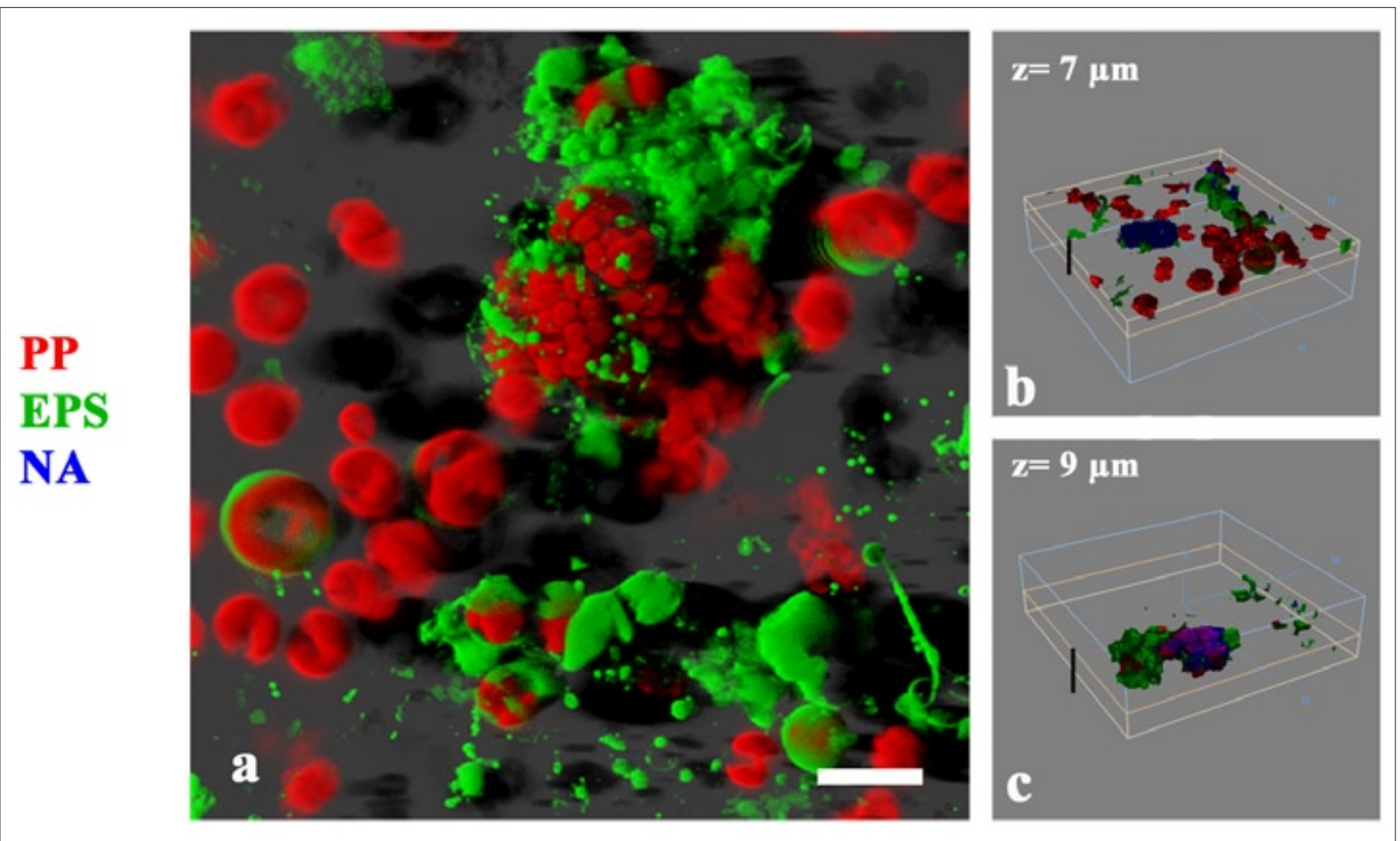

Fig. 5. Confocal photomicrographs. Structure and composition of a stratified Type 2 biofilm in Zuheros (Z4). a. Two-channel image created by the Simulated Fluorescence Projection (SFP) method of $69 x-y$ optical sections $(z$ step $=0.3 \mu \mathrm{m}$ ). Thickness $=20.40 \mu \mathrm{m}$. b. c. 3D perspective projection in the ray-tracing method of Fig. 5a. Selected regions from top and bottom levels; each level has a particular microbial composition and mucilage abundance. b. The surface level of the biofilm $(Z=7 \mu \mathrm{m})$ is mainly composed of Myrmecia bisecta (Chlorophyta). c. The bottom level $(Z=9 \mu \mathrm{m})$ is composed of Cyanosarcina cf. parthenonensis (Chroococcales) which is sometimes located in deeper parts of the substratum (chasmoendolithic growth) (scale: $10 \mu \mathrm{m}$ ). Colour key: red = autofluorescence of pigments (PP); green = EPS labelled Con-A (EPS); nucleic acids (NA).

which exhibited a thin calcified external sheath. This species was entangled with Leptolyngbya spp., Klebsormidium flaccidum and moss protonema. The diatom Diadesmis contenta and the green algae Chlorella sp., Coccobotrys verrucariae and Myrmecia biatorellae were located primarily at the top and were irregularly distributed. Spots of Nostoc punctiforme and Gloeocapsopsis magma were located deep within the substrata (chasmoendolithic growth). The structure of the biofilm was due to Scytonema julianum, (Fig. 7 d, Type 6 biofilm) which was sometimes accompanied by other filamentous cyanobacteria or mosses. Any diatom present was located in the upper layer.

All these microscopy observations revealed that the community of microorganisms were organised in biofilms characterised by spatial structure. The patinas appeared to be distributed spatially and were very heterogeneous in thickness, density and organism composition. The biofilms were compact and thin, from 6.45 to $25.47 \mu \mathrm{m}$ thick in Zuheros, although they appeared thicker when moulding the substrata irregularities (from 50.31 to $167 \mu \mathrm{m}$ ). This indicates a very rough substratum, which was even more irregular in Nerja, in which the layer of photosynthetic organisms traced the highly irregular surfaces. As a rule, the biofilms were less than 1 $\mathrm{mm}$ thick, except in humid areas close to lamps, where mosses contributed to the structure. EPS were irregularly distributed in the biofilms and were more abundant in the upper layers. The cyanobacteria were on top of the substrata or were hidden in it, whereas the green algae were always found on the surface, whether growing directly on the substrate or on top of the other organisms in the biofilm. No endolithic growth was observed. Schematics of Types 1 to 6 biofilms are illustrated in Fig. 8 a-f.

\section{DISCUSSION}

The examples described above are all cave habitats; from an anthropocentric perspective, this translates to hypogean and dark. Hence, their primary common stress factor is light shortage, followed by humidity, a lack of nutrients, and to a far lesser extent, temperature (Smith \& Olson, 2007). The amount of light varies with cave type. It also varies within caves according to gradients from the mouth to the interior.

Areas near cave entrances are generally affected by environmental changes and show major fluctuations (Hoffmann, 2002; Roldán et al., 2004b; Vinogradova et al., 1998). In the spring and at the end of the summer, the afternoon light remains intense, coinciding with maximum temperature and minimum relative humidity. Temperature, relative humidity and light show a clear gradient from the entrance up to a certain depth of the interior of the cave, beyond which 


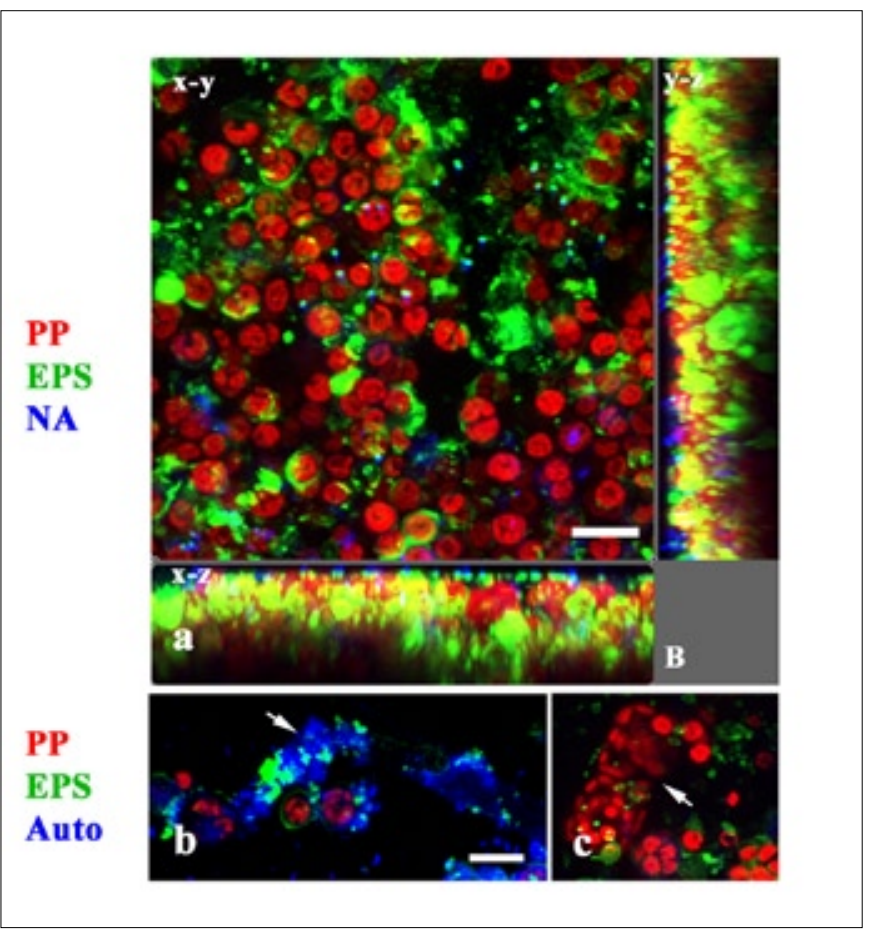

Fig. 6. Confocal photomicrographs. Structure and composition of a Type 5 biofilm in Zuheros (Z7). Sampling points near the exit, with natural light. a. Biofilm formed by an upper layer of the leprose lichen Botryolepraria lesdainii, with or without diatoms, and a bottom layer of Coccobotrys verrucariae (Chlorophyta), either lichenised or free-living ( $B=$ bottom of the sample). Three-dimensional extended projection in $x-y, x-z$ and $y-z$ views of 90 optical sections ( $z$ step $=0.2 \mu \mathrm{m}$ ) in the $z$-direction of the biofilm. Thickness $=17.80 \mu \mathrm{m}$ (scale: $10 \mu \mathrm{m}$ ). b. Some lichens presented natural blue fluorescence (white arrow). c. Associated organisms were other green algae such as Trebouxia sp. and diatoms (e.g. Orthoseira roeseana, white arrow) (scale: 10 $\mu \mathrm{m})$. Colour key: red $=$ autofluorescence of photosynthetic pigments $(\mathrm{PP})$; green = EPS labelled Con-A (EPS); blue = nucleic acids (NA) or autofluorescence of lichens (Auto).

they remain stable. Deep within the cave, relative humidity is usually high (Pentecost $\&$ Whitton, 2000); there is little or no variation during the diurnal cycle, and only slight differences were observed between the measurements from rainy and arid seasons, and between those from winter and summer. From the mouth of the cave to the furthest sampling point inside, the organisms were organised into mosaics or belts according to environmental conditions. The diversity of microalgal and cyanobacterial species decreased with decreasing light (Roldán et al., 2004b).

Approximately 350 taxa of photoautotrophic microflora have been reported for hypogean environments, although some of these were identified in culture and are unable to survive in dim environments (Hoffmann, 2002). The caves whose literature was surveyed for this work either exhibited a much lower total number of species (Asencio \& Aboal, 2000; Friedmann, 1964; Vinogradova et. al., 1998; Roldán et al., 2004b), or only their cyanobacteria were studied, which nevertheless represent more than half of the total taxa and tend to dominate with associations similar to those described by Golubic (1967) and those cited in the review by Pentecost \& Whitton (2000). Coccoid forms are more abundant

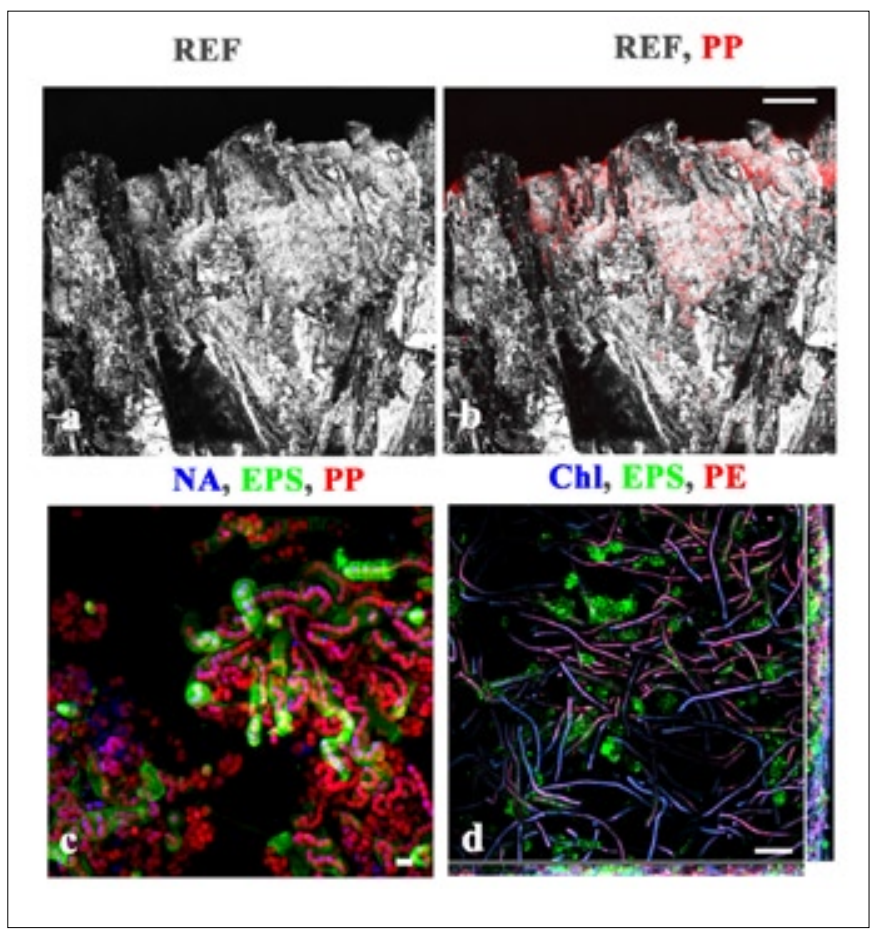

Fig. 7. Confocal photomicrographs. a. Reflection projection showing inorganic calcareous material from Nerja (N5). b. Reflection, as in Fig. 7, a, plus spatial distribution of pigment autofluorescence. Single celled chlorophytes are distributed in a thin layer penetrating the fissures and fractures (chasmoendolithic growth) (scale: $100 \mu \mathrm{m}$ ). c. Maximum intensity projection from a biofilm composed of Nostoc sp. (N6), showing colonies with and without EPS production (scale: $10 \mu \mathrm{m})$. d. Structure and composition of a Type 6 biofilm in Collbató (Virgin Cave) formed mainly of Scytonema julianum. Chlorophyll-a and phycoeritrin autofluorescences can be distinguished in different emission wavelengths (scale: $100 \mu \mathrm{m}$ ). Colour key: white = reflection (REF); red = autofluorescence of photosynthetic pigments (PP) or phycoerithrin $(\mathrm{PE})$; green = EPS labelled Con-A $(E P S)$, blue = nucleic acids (NA) or autofluorescence of chlorophyll a (Chl).

in illuminated areas and dripping sites. Filamentous forms tend to be more diverse in darker or more humid locations (Vinogradova et al., 1998). Exceptions include Scytonema julianum, which can bear strong fluctuations (Leclerc et al., 1983; Coute \& Bury, 1988): it thrives in sheltered walls that receive light peaks of $1800 \mu \mathrm{E} \mathrm{m}^{-2} \mathrm{~s}^{-1}$, yet it grows in culture down to $21 \mu \mathrm{E} \mathrm{m}^{-2} \mathrm{~s}^{-1}$ (Ariño et al., 1997) and can grow in caves with relatively low humidity (down to ca. 50\%) (Aboal et al., 1994).

In contrast, other filamentous cyanobacteria such as Geitleria calcarea, Herpyzonema pulverulentum and Loriella sp. require long term stability and humidity near the dew point and grow slowly in levels of light down to $1 \mu \mathrm{E} \mathrm{m}^{-2} \mathrm{~s}^{-1}$ (Ariño et al., 1997, Leclerc et al., 1983, Roldán et al., 2004b); none of these were found during this study.

For environments in which the only source of light is artificial, the number of species is even lower; this is true for caves (Smith \& Olson, 2007) as well as similar hypogean environments (Albertano et al., 1994, 2003), in which mosses and green algae are more abundant near the lamps, provided that the ambient humidity is near the saturation point or there is dripping. In these artificial habitats, in which 


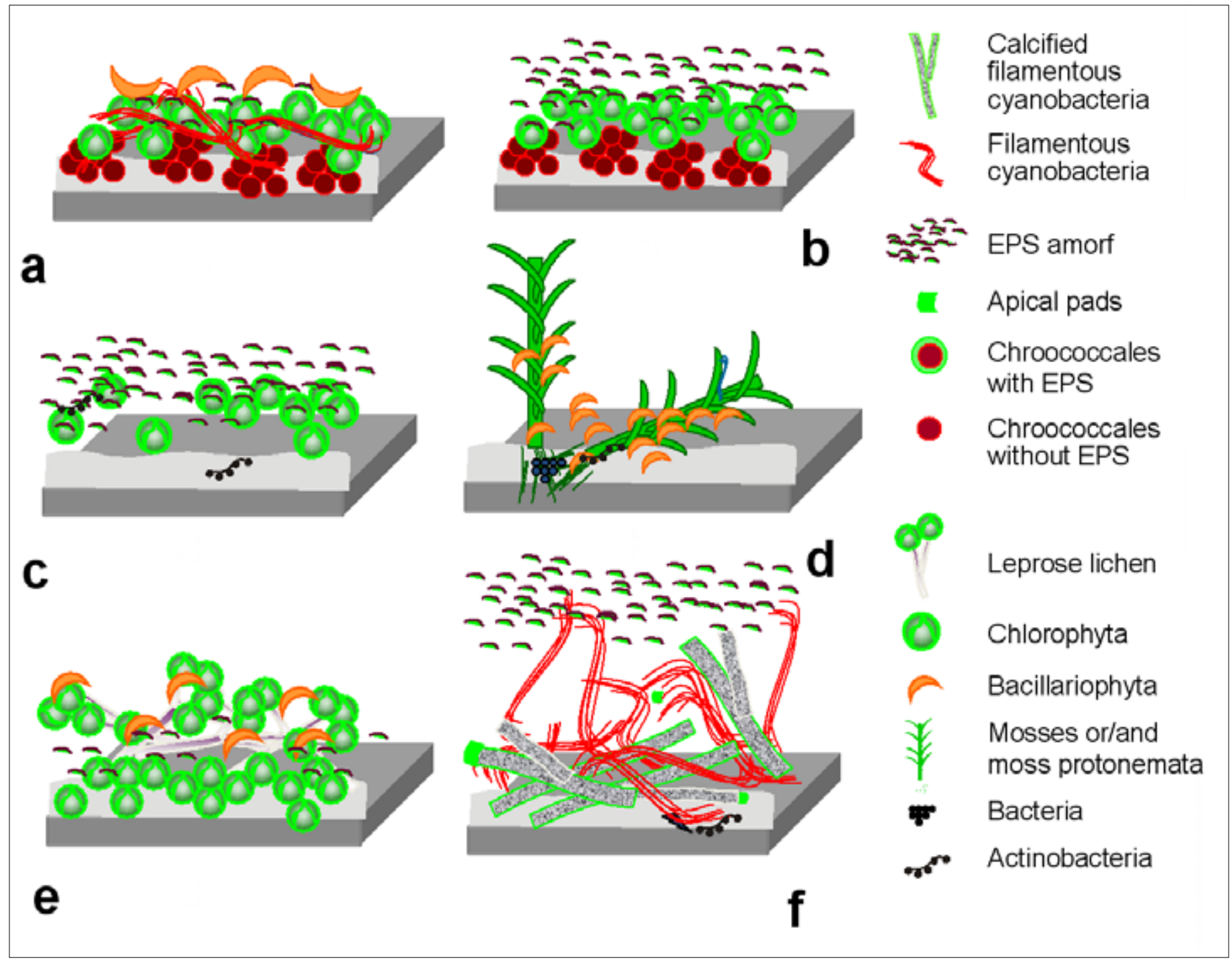

Fig. 8. Conceptual drawings of biofilm structure (Types 1-6) from different caves on various substrata, according to species dominance and depth distribution inside the biofilm. a. Type 1 biofilm: encompassed several taxa and generally exhibited stratification, with a continuous upper layer of chlorophytes and diatoms and a discontinuous bottom layer of cyanobacteria. b. Type 2 biofilm: formed by very few photosynthetic organisms, but still stratified. c. Type 3 biofilm: formed by one or very few organisms, without stratification. d. Type 4 biofilm: Formed by mosses or moss protonemata plus other photosynthetic organisms. e. Type 5 biofilm: formed by lichens plus other photosynthetic organisms. f. Type 6 biofilm: structured by calcified cyanobacteria in addition to other photosynthetic organisms.

light is not continuous, the additional stress factor which appears to compromise the diversity of taxa is stability. The most affected species are cyanobacteria, which can not grow fast enough in these transient habitats. Diatoms are also affected, although their quantification is not easy, owing to their resistant valves, which remain even when they are dead. Measurements by CLSM-which enables separate observation of live diatoms (which fluoresce) from dead ones (which do not fluoresce)-can be used as an indicator of activity, and consequently, as a tool to determine the health of populations. Hence, an increase in levels of scavengers or actinobacteria at certain points suggests population substitution as a result of variable conditions.

Photosynthetic microorganisms exhibit considerable interspecific variation in their ability to persist under prolonged darkness (Albertano et al., 1991). To withstand extended periods of light deprivation, photosynthetic cells must maintain viability. The conditions of light deprivation and burial have been widely studied in lakes and rivers. The same taxa capable of tolerating conditions of low light are also likely to exhibit high resistance to prolonged light deprivation (Peterson, 1996). Another factor that can favour long-term survival in low- or zero-light conditions is heterotrophy. Although most microalgae and cyanobacteria grow photoautotrophically, some can grow heterotrophically. Owing to Chodat's (1909) pioneering work on the culture of microscopic algae, including Chlorella and Coccomixa, the capacity to which these organisms can grown on organic substrata is known: they grow heterotrophically via an active glucose uptake system. This process has been described for phototrophic cells (Chen \& Chen, 2006), including Plectonema boryanum (Raboy \& Padan, 1978), which has been broadly described in caves.

The aforementioned differences among the organisms and in the physicochemical characteristics of the environment could explain the species assemblies and microscale structural organisation. The biofilms described from the entry (Types $1-3$ biofilms) and the 
exit (Type 5 biofilm) of Zuheros are characteristic of the mouths of caves (Hernández-Mariné et al., 2001b; Ariño et al., 1997). A gradient was observed in which the diversity and thickness of biofilms decreased with decreasing light. Type 1 biofilm was marked by vertical stratification, apparently following the vertical gradient of light, whereby diatoms and green algae are located on the surface, and cyanobacteria are located at the bottom. In contrast, Type 3 biofilm was unstructured and comprised of one to a few taxa; dominant chlorophytes that they contain can be considered taxa characteristic of early colonisation. The green colour of these biofilms, as well as the lack of colour in areas adjacent to those in which they grow, which are exposed to the same light, may be indicative of a lack of water during dry periods. Type 3 biofilm found on highly irregular substrates (e.g. those of Nerja N5) were observed to grow deep into the interior of rocks up to the point at which light was insufficient, exhibiting chasmoendolithic growth. Mosses only dominated at dripping points close to light sources. On top of the mosses were found other organisms, such as diatoms or filamentous cyanobacteria (Albertano et al., 1994). Type 6 biofilm was heterogeneous in structure and primarily composed of Scytonema julianum.

The three-dimensional structures of biofilms from many other extreme environments have been described. This has required that the techniques for sampling and observation do not compromise the architecture itself. Examples can be found for hot and cold deserts, (Wynn-Williams, 2000 and references therein), desert soil crusts (GarciaPichel \& Belnap, 1996; Nienow \& Friedmann, 1993), endolithic environments (Walker \& Pace 2007), and extremely acidic environments (Aguilera et al., 2007), in which micrometre scale stratification can be observed. Vertical zonation is especially visible in the benthic microbial mat communities of Antarctica (Vincent, 2000), in which blue-green coloured strata, usually located towards the bottom of the mats, have been described. This heterogeneous distribution reflects different adaptation strategies used by microorganisms, and should provide certain advantages, at least for some of the constituent microorganisms in the structure. Understanding the factors that control the microorganisms as well as the effects of environmental stress on biofilm formation in $\operatorname{dim}$ habitats will require further studies employing better methods than those currently available.

\section{ACKNOWLEDGEMENTS}

This work was supported by the EU Energy, Environment and Sustainable Development programme as part of the CATS Project (contract EVK4-CT-2000-00028) and by the Spanish Ministerio de Educación y Ciencia (project CGL06-07242). The authors thank the Scientific and Technical Services of the University of Barcelona for technical assistance. They also express their gratitude to the staff of the Cueva de Zuheros, the Ajuntament de Collbato and the Fundacion Cueva de Nerja for enabling this study. Lastly, the authors thank the CATS team, especially
Dr. Patrizia Albertano, for their contribution of information.

\section{REFERENCES}

Abdelahad N., 1989 - On four Myxosarcina-like species (Cyanophyta) living in the Inferniglio cave (Italy). Archiv für Hydrobiologie, Supplement Algological Studies, 54: 3-13.

Abdelahad N. \& Bazzichelli G., 1988 - Geitleria calcarea Friedmann, Cyanophycée cavernicole nouvelle pour l'Italie. Nova Hedwigia, 46: 265-270.

Aboal M. , Asencio A. D. \& Prefasi M., 1994 - Studies on cave cyanophytes from southeastern Spain: Scytonema julianum. Archiv für Hydrobiologie, Supplement Algological Studies, 75: 31-36.

Aguilera A., Souza-Egipsy V., Gómez F. \& Amils R., 2007 - Development and Structure of Eukaryotic Biofilms in an Extreme Acidic Environment, Rio Tinto (SW, Spain). Microbial Ecology, 53: 294-305.

Albertano P., Kovacik L. \& Grilli Caiola M., 1994 Preliminary investigations on epilithic cyanophytes from a Roman Necropolis. Archiv für Hydrobiologie, Supplement Algological Studies, 75: 71-74.

Albertano P. , Luongo L. \& Grilli Caiola M. , 1991 - Influence of different lights on mixed cultures of microalgae from ancient frescoes. International Biodeterioration \& Biodegradation, 27: 27-38.

Albertano P., Moscone D., Palleschi G., Hermosin B., Saiz-Jimenez C., Sánchez-Moral S., M. HernándezMariné M., Urzi C., Groth I., Schroeckh V., Saarela M., Mattla Sandholm T., Gallon J.R., Graziottin F., Bisconti F. \& Giuliani R., 2003 - Cyanobacteria attack rocks (CATS): control and preventive strategies to avoid damage caused by cyanobacteria and associated microorganisms in Roman hypogean monuments. In: Saiz-Jimenez C (editor), Molecular Biology and Cultural Heritage. Lisse, Balkema. 302-315.

Albertano P. \& Urzi C., 1999 - Structural interactions among epilithic cyanobacteria and heterotrophic microorganism in Roman hypogea. Microbial Ecology, 38: 244-52.

Anagnostidis K., Economou-AmilliA. \&Roussomoustakaki M., 1983 - Epilithic and chasmoendolithic microflora (Cyanophyta, Bacillariophyta) from marbles of the Parthenon (Acropolis-Athens, Greece). Nova Hedwigia, 38: 227-287.

Ariño X., Hernández-Mariné M. \& Saiz-Jiménez C., 1997 - Colonization of Roman tombs by calcifying cyanobacteria. Phycologia, 36: 366-373.

Asencio A. D., Aboal M. \& Hoffmann L., 1996 - A new caveinhabitingblue-greenalga: Symphyonemacavernicolum sp. nova (Mastigocladaceae, Stigonematales). Archiv für Hydrobiologie, Supplement Algological Studies, 83: 73-82.

Asencio A. D. \& Aboal M., 2000 - Algae from La Serreta cave (Murcia, SE Spain) and their environmental conditions. Archiv für Hydrobiologie, Supplement Algological Studies, 96: 59-78.

Bagge D., Hjelm M., Johansen C., Huber I. \& Gram L., 2001 - Shewanella putrefaciens adhesion and biofilm formation on food processing surfaces. Applied and Environmental Microbiology, 67: 2319-2325. 
Borzi A., 1917 - Studi sulle Mixoficée. Nuovo Giornale Botanico Italiano, 24: 100-112.

Bourrelly P. \& Dupuy P., 1973 - Quelques stations françaises de Geitleria calcarea, Cyanophycée cavernicole. Schweizerische Zeitschrift für Hydrology, Fischereiwissenschaft, Abwassereinigung, 35: 136140.

Brading M. G., Boyle J. \& Lappin-Scott H. M., 1995 Biofilm formation in laminar flow using Pseudomonas fluorescens $E X$ 101. Journal of Industrial Microbiology, 15: 297-304.

Bryers J. D., 1987 - Biologically active surfaces: Processes governing the formation and persistence of biofilms. Biotechnology Progress 3: 57-68.

Carter J. R., 1971 - Diatoms from the Devil's hole cave Fife, Scotland. Nova Hedwigia, 21: 657-681.

Chen G. Q. \& Chen F., 2006 - Growing phototrophic cells without light. Biotechnology Letters, 28: 607-616.

Chodat R., 1909 - Étude critique et expérimentale sur le polymorphisme des algues. Georg \& Cie. Genève, 165 p.

Claus G., 1964 - Algae and their mode of life in the Baradla Cave at Aggtelek II. International Journal of Speleology, 1: 13-17.

Costerton J. W., Cheng K. J., Geesey K. G., Ladd P. I., Nickel J. C., Dasgupta M. \& Marrie T. J., 1987 Bacterial biofilms in nature and disease. Annual Review of Microbiology, 41: 435-64.

Couté A. \& Bury E., 1988 - Ultrastructure d'une cyanophycée aérienne calcifiée cavernicole: Scytonema julianum (Frank) Richter (Hormogonophycideae, Nostocales, Scytonemataceae). Hydrobiologia, 160: 219-239.

Crispim C. A., Gaylarde P. M. \& Gaylarde C. C., 2003 Algal and cyanobacterial biofilms on calcareous historic buildings. Current Microbiology, 46: 79- 82.

Danin A. \& Caneva G., 1990 - Deterioration of limestone walls in Jerusalem and marble monuments in Rome caused by cyanobacteria and cyanophilous lichens. International Biodeterioration, 26: 397-417.

Davis J. S. \& Rands D. G., 1981 - The genus Geitleria (Cyanophyceae) in a Bahamian cave. Schweizerische Zeitschrift für Hydrology, Fischereiwissenschaft, Abwassereinigung, 43: 63-68.

Davey M. \& O'Toole G. A., 2000. - Microbial Biofilms: from Ecology to Molecular Genetics. Microbiology and Molecular Biology Reviews, 64: 847-867.

Dobat K., 1977 - Zur Ökogenese und Ökologie der Lampenflora deutscher Schauhöhlen. In: Frey, W. (Editor) Beiträge zur Biologie der niederen Pflanzen. Gustav Fischer Verlag, Stuttgart: 177-215.

Ettl H. \& Gärtner G., 1995 - Syllabus der Boden-, Luft-, und Flechtenalgen. Gustav Fischer: New York: 710 p.

Friedmann, I. 1955 - Geitleria calcarea n. gen. and n. sp. Botaniska Notiser, 108: 439-445.

Friedmann I., 1964 - Progress in the biological exploration of caves and subterranean waters in Israel. International Journal of Speleology, 1: 29-33.

Friedmann I., 1979 - The genus Geitleria (Cyanophyceae or Cyanobacteria): Distribution of G. calcarea and G. floridana $n$. sp. Plant Systematics and Evolution, 131: 169-178.
Garbacki N., Ector L., Kostikov I. \& Hoffmann L., 1999 - Contribution à l'étude de la flore des grottes de Belgique. Belgian Journal of Botany, 132: 4376.

Garcia-PichelF. \& BelnapJ., 1996 - Microenvironments and microscale productivity of cyanobacterial desert crusts. Journal of Phycology, 32: 774-782.

Golubic S., 1967 - Algenvegetation der Felsen, eine ökologische Algenstudie im dinarischen Karstgebiet. In: A Elster, H. J. \& Ohle, W. (Eds.), Die Binnengewässer. Vol. 23. Schweizerbart'sche Verlagsbuchhandlung, Stuttgart, 183 p.

Golubic S., Friedmann I. \& Schneider J., 1981 - The lithobiontic ecological niche, with special reference to microorganisms. Journal of Sedimentary Research, 51: 475-478.

Golubic S. \& Schneider J., 2003 - Microbial endoliths as internal biofilms. In: Krumbein W.E. Dornieden T. , Volkmann M. , Paterson D.M. \& Zavarzin G.A. (Eds.), Fossil and Recent Biofilms. A natural History of Life on Earth. Kluwer Academic Publishers, Dordrecht: 249-263.

Gracia Alonso C. A., 1974 - Geitleria calcarea Friedmann nueva alga cavernícola para España. Speleon (Barcelona), 21: 133-136.

Grilli Caiola M., Forni C. \& Albertano P., 1987 Characterization of the algal flora growing on ancient Roman frescoes. Phycologia, 26: 387-396.

Hajdu I., 1966 - Algological studies in the cave of Matyas Mount, Budapest, Hungary. International Journal of Speleology, 2: 137-149.

Hall-Stoodley L., Costerton J.W. \& Stoodley P., 2004 - Bacterial biofilms: from the natural environment to infectious diseases. Nature Reviews, 2: 95-106.

Hernández-Mariné M. \& Canals A., 1994a Cianoficeas filamentosas cavernícolas. Stvdia Botanica, 13: 227-229.

Hernández-Mariné M. \& Canals T., 1994b Herpyzonema pulverulentum (Mastigocladaceae), a new cavernicolous atmophytic and lime-incrusted cyanophyte. Archiv für Hydrobiologie, Supplement Algological Studies, 75: 123-136.

Hernández-Mariné M., Asencio-Martínez A., Canals A., Ariño X., Aboal M. \& Hoffmann L., 1999 - Discovery of populations of the lime incrusting genus Loriella (Stigonematales) in Spanish caves. Archiv für Hydrobiologie, Supplement Algological Studies, 94: 121-138.

Hernández-Mariné M., Martinez G., Dominguez A., Fontarnau R. \& Cortadellas N., 2001a - SEM studies of arborescent aerophytic biofilms. Use of acrolein and osmium vapour impregnation. In: Microscopy: p. 334-335, Universitat de Barcelona, Barcelona: 334-335

Hernández-Mariné M., Roldán M., Clavero E., Canals A. \& Ariño X., 2001b - Phototrophic biofilm morphology in dim light. The case of the Puigmolto sinkhole. Nova Hedwigia, 123: 237-253.

Hernández-Mariné M., Clavero E. \& Roldán M., 2003 Why there is such luxurious growth in the hypogean environments. Archiv für Hydrobiologie, Supplement Algological Studies, 109: 229-240. 
Hernanz A., Mas M., Gavilán B. \& Hernández B. 2006 Raman microscopy and IR spectroscopy of prehistoric paintings from Los Murciélagos cave (Zuheros, Córdoba, Spain). Journal of Raman Spectroscopy, 37: 492-497.

Hoffmann L. 1989 - Algae of terrestrial habitats. In: Cronquist, A. (Ed.) The Botanical Review. 55. The New York Botanical Garden, Bronx, NY: 77-105.

Hoffmann L. 2002 - Caves and otherlow-lightenvironments: Aerophytic photoautotrophic microorganisms. In: Bitton G. (Ed.), Encyclopedia of Environmental Microbiology. John Wiley \& Sons, New York: 835-843.

Kol E., 1966 - Algal growth experiments in the Baradla Cave at Aggletek. International Journal of Speleology, 2: 457-474.

Komáromy Z. P., 1977 - The algal flora of the Ördöglyuk Cave at Szoplak (Hungary). Annales Historico-naturales Musei Nationalis Hungarici, 69: 29-35.

Komáromy Z. P., Padisák J. \& Rajczy M., 1985 - Flora in the lamp-lit areas of the cave "Annabarlang" near Lillafüred (Hungary). Annales Historico-naturales Musei Nationalis Hungarici, 77: 103-122.

Korber D. R., James G. A., \& Costerton J. W., 1994 Evaluation of fleroxacin activity against established Pseudomonas fluorecens biofilms. Applied and Environmental Microbiology, 60: 1663-1669.

Kumar C. G. \& Anand S. K., 1998 - Significance of microbial biofilms in food industry: a review. International Journal of Food Microbiology, 42: 9-27.

Kumar R. \& Kumar A. V., 1999 - Biodeterioration of stone in tropical environments. Research in Conservation, Getty Conservation Institute, Los Angeles, 85 p.

Kumar N. S., Kumar R., Singh S. \& Brown R. M. Jr., 2007 - Airborne algae: their present status and relevance. Journal of Phycology, 43: 615-627.

Leclerc J. C., Couté A. \& Dupuy P., 1983 - Le climat annuel de deux grottes et d'une église du Poitou, ou vivent des colonies pures d'algues sciaphiles. Cryptogamie Algologie, 4: 1-19.

Lefèvre M., 1974 - La maladie verte de Lascaux. Studies in Conservation, 19: 126-156.

Lefèvre M., Laporte G. \& Bauer J., 1964 - Sur les microorganismes envahissant les peintures rupestres de la grotte préhistorique de Lascaux. Comptes Rendus de l'Académie des Sciences, 258: 5116-5118.

McEldowney S. \& Fletcher M., 1987 - Adhesion of bacteria from mixed cell suspension to solid surfaces. Archives of Microbiology, 148: 57-62.

Nienow J. A. \& Friedmann I., 1993 - Terrestrial lithophytic (rock) communities.In: Friedmann E.I. (Ed.) Antarctic Microbiology. Wiley-Liss, New York: 343-412.

Ohki K. \& Gantt E., 1983 - Functional phycobilisomes from Tolypothrix tenuis (Cyanophyta) grown heterotrophycally in the dark. Journal of Phycology, 19: 359-364.

Ortega-Calvo J. J., Hernández-Mariné M. \& Saiz-Jiménez C., 1991 - Biodeterioration of building materials by cyanobacteria and algae. International Biodeterioration, 28: $165-185$.

Ortega-Calvo J. J., Sánchez-Castillo P. M., HernándezMariné M. \& Saiz-Jiménez C., 1993 - Isolation and characterization of epilithic chlorophytes and cyanobacteria from two Spanish cathedrals (Salamanca and Toledo). Nova Hedwigia, 57: 239-253.
Pentecost A. \& Whitton B. A., 2000 - Limestones. In: B. A.Whitton \& M. Potts (Eds.), The Ecology of Cyanobacteria. Kluwer Academic Publishers. Dordrecht: 257-279.

Peterson C. G., 1996 - Responses of benthic algal communities to natural physical disturbance. In: R. J. Stevenson, M. L. Bothwell \& R. L. Lowe (Eds). Algal Ecology. Academic Press, California: 375-398.

Pietrini A. M. \& Ricci S., 1993 - Occurrence of a calcareous blue-green alga, Scytonema julianum (Kütz) Meneghini, on the frescoes of a church carved from the rock in Matera, Italy. Cryptogamy Botany, 3: 290-295.

Prakash B., Veeregowda B. M. \& Krishnappa G., 2003 Biofilms: a survival strategy of bacteria. Current Science, 85:1299-1307.

Raboy B. \& Padan E., 1978 - Active transport of glucose and alpha-methyglucoside in cyanobacterium Plectonema boryanum. Journal of Biological Chemistry, 253: 32873291.

Roldán, M., Clavero E., Castel S. \& HernándezMariné M., 2004a - Biofilms fluorescence and image analysis in hypogean monuments research. Archiv für Hydrobiologie, Supplement Algological Studies, 111:127-143.

Roldán M., Clavero E., Canals A., Gómez-Bolea A., Ariño X. \& Hernández-Mariné M., 2004b - Distribution of phototrophic biofilms in cavities (Garraf, Spain). Nova Hedwigia., 78: 329-351.

Saint-Clair L. \& Rushforth R., 1976 - The diatoms of Timpanogos Cave National Monument, Utah. American Journal of Botany, 63: 49-59.

Saint-Clair L., Rushforth S. \& Allen J., 1981 - Diatoms of Oregon caves national monument, Oregon. Great Basin Naturalist, 41: 317-332.

Sánchez Castillo P., 1981 - Cianofitas en la ciudad de Granada. Trabajos del Departamento de Botánica. Universidad de Granada, 6: 29-48.

Sánchez Castillo P., 1983 - Clorofitas en la ciudad de Granada. Trabajos del Departamento de Botánica. Universidad de Granada, 8: 63-79.

Sanchidrián J. L. 1986 - El arte prehistórico de la Cueva de Nerja. In: Jordá F. \& Pellicer M. (Eds), La Prehistoria de la Cueva de Nerja (Málaga). Málaga: 284-330.

Sant'Anna C. L., Branco L. H. Z. \& Silva S. M. F., 1991 - A new species of Gloeothece (Cyanophyceae, Microcystaceae) from Sao Paulo State, Brazil. Archiv für Hydrobiologie, Supplement Algological Studies, 62: $1-5$.

Serbanescu M. \& Decu V., 1962 - To the knowledge of cavernicolous algae of Oltenia. Revue de Biologie, 7: 201-214.

Skuja H., 1970 - Alghe cavernicole nelle zone illuminate delle grotte di Castellana (Murge di Bari). Le Grotte d'Italia, 4: 193-202.

Smith T. \& Olson R., 2007 - A taxonomic survey of Lamp Flora (Algae and Cyanobacteria) in electricaly lit passages within Mammoth Cave National Park, Kentuky. International Journal of Speleology, 36: 105-114.

Stewart P. S., 1997 - Theoretical aspects of antibiotic diffusion into microbial biofilms. Antimicrobial Agents and Chemotherapy, 40: 2517-2522. 
Tomaselli L., Lamenti G., Bosco M. \& Tiano P., 2000 Biodiversity of photosynthetic microorganisms dwelling on stone monuments. International Biodeterioration \& Biodegradation, 46: 251-258.

Vincent W. F., 2000 - Cyanobacterial dominance in the Polar regions. In: Whitton B. A.\& Potts M. (Eds.), The Ecology of Cyanobacteria. Kluwer Academic Publishers. Dordrecht: 321-340.

Vinogradova O. N., Kovalenko O. V., Wasser S. P., Nevo E. \& Weinstein-Evron M., 1998 - Species diversity gradient to darkness stress in blue-green algae/cyanobacteria: a microscale test in a prehistoric cave, Mount Carmel, Israel. Israel Journal of Plant Sciences, 46: 229-238.
Walker J. J. \& Pace N. R., 2007 - Endolithic Microbial Ecosystems. Annual Review of Microbiology, 61: 331347.

Wimpenny J., Manz W. \& Szewzyk U., 2000 Heterogeneity in biofilms. FEMS Microbiology Reviews, 24: 661-671.

Wynn-Williams D. D., 2000 - Cyanobacteria in DesertsLife at the Limit?. In: B. A.Whitton \& M. Potts (Eds.) - The Ecology of Cyanobacteria. Kluwer Academic Publishers. Dordrecht: 341-366.

Zhang T. \& Bishop P., 1994 - Structure, activity and composition of biofilms. Water Science and Technology, 29: 263-270. 